\title{
The effect of chloride and nitrogen on nitrate accumulation and yield in beetroot (Beta vulgaris var. conditiva)
}

\author{
TAPio Salo, LiISA PIETOla and RaIli Jokinen
}

\begin{abstract}
Salo, T., Pietola, L. \& Jokinen, R. 1992. The effect of chloride and nitrogen on nitrate accumulation and yield in beetroot (Beta vulgaris var. conditiva). Agric. Sci. Finl. 1: 351-360. (Agric. Res. Centre of Finland, Inst. Crop and Soil Sci., SF31600 Jokioinen, Finland.)

A pot and a field experiment were conducted to evaluate the effects of different nitrogen and chloride fertilizer levels on the nitrate content of beetroot. The yield and dry matter content were also determined. Sulphate fertilization was used as a control to chloride fertilization.

There was a considerable decrease in the nitrate content of beetroots during the growing season. High nitrogen fertilization caused nitrate accumulation in both experiments.

Chloride had a significant decreasing effect on the nitrate accumulation towards the middle of the growing period in the pot experiment. In the field experiment, chloride also decreased nitrate accumulation towards the middle of the growing period, soon after additional application of ammonium nitrate limestone $\left(13.8 \% \mathrm{NH}_{4}-\mathrm{N} ; 13.7 \%\right.$ $\mathrm{NO}_{3}-\mathrm{N}$ ). Chloride tends to decrease nitrate accumulation only at an early stage of root development when nitrate is not the only source of nitrogen in the soil.

The yield was higher on high nitrogen supply, in the pot experiment also on chloride application. Nitrogen decreased the dry matter content, but chloride had this effect only in the field experiment.
\end{abstract}

Key words: ammonium nitrate, fertilization, vegetables, dry matter

\section{Introduction}

High nitrate levels in human food are undesirable, because nitrate may be converted into nitrite which causes methemoglobinemia or is converted into carcinogenic nitrosoamines. Vegetables are the main source of nitrate in the Finnish diet (PENTTILÄ et al. 1990).

Chloride in the soil is antagonistic to nitrate uptake (JAMES et al. 1970). According to HÄHNDEL and WEHRMANN (1986 b), reduction of the nitrogen supply and addition of chloride decreases considerably the nitrate contents of spinach and lettuce. Van der Boon et al. (1988) reported that a high level of chloride decreases the nitrate content of lettuce and suggested that, in the presence of ammonium nitrogen, chloride may replace nitrate as a vacuolar osmoticum. Chloride may also replace nitrate as a counter-anion of cations (ALLEN and SMITH 1986).

The experiments reported here were conducted to find out, whether chloride has the same effect on the nitrate content in beetroot as in lettuce or spinach. The pot experiment was carried out during the growing season of 1989 on an organic soil and the field experiment during the growing season of 1990 on a clay loam soil. 


\section{Material and methods}

The experiments were carried out in Jokioinen $\left(60^{\circ} 49^{\prime} \mathrm{N} ; 2^{\circ} 28^{\prime} \mathrm{E}\right)$. The experimental soils were analyzed for potassium, phosphorus, calcium and magnesium extractable in acid ( $\mathrm{pH} \mathrm{4.65)} \mathrm{ammo-}$ nium acetate (VUORINEN and MÄKINEN 1955, KURKI et al. 1965), as well as pH and electrical conductivity (EC) in water suspension. The soil EC was determined also after the growing season. The boron content was determined by the azomethineH method (SIPPOLA and ERVIÖ 1977), the organic carbon content by a Leco-analyzer at $1370{ }^{\circ} \mathrm{C}$ (SIPPOLA 1982) and the particle size distribution by the method of ELONEN (1971). The characteristics of experimental soils are presented in Table 1.

Table 1. Characteristics of experimental soils

\begin{tabular}{lrr}
\hline & Pot soil & Field soil \\
org. C, \% & 15.3 & 2.7 \\
particle size & & \\
$\quad<2 \mu \mathrm{m}, \%$ & 80.5 & 40.5 \\
$2-20 \mu \mathrm{m}, \%$ & 10.1 & 25.8 \\
$>20 \mu \mathrm{m}, \%$ & 9.4 & 33.7 \\
$\mathrm{pH}_{\mathrm{w}}$, & 5.4 & 6.7 \\
$\mathrm{EC}, 10^{-4} \mathrm{~S} / \mathrm{cm}$ & 1.1 & 5.9 \\
$\mathrm{P}, \mathrm{mg} / \mathrm{l} \mathrm{soil}$ & 8.2 & 48.8 \\
$\mathrm{~K},-"-$ & 403 & 260 \\
$\mathrm{Ca},-"-$ & 2710 & 3257 \\
$\mathrm{Mg},-"-$ & 294 & 414 \\
$\mathrm{~B},-"-$ & 0.6 & 1.5 \\
\hline
\end{tabular}

\section{Pot experiment}

The pot experiment was set up according to the split-plot design, where the main plot was nitrogen fertilization $\left(\mathrm{N}_{0}, \mathrm{~N}_{250}, \mathrm{~N}_{500}, \mathrm{~N}_{750}, \mathrm{~N}_{500+250}\right)$ and the subplot $\mathrm{NaCl}$ fertilization $\left(\mathrm{Cl}_{250}, \mathrm{Cl}_{500}\right)$ or $\mathrm{Na}_{2} \mathrm{SO}_{4}$ fertilization $\left(\mathrm{S}_{113}, \mathrm{~S}_{225}\right)$. A total of twenty treatments were compared (Table 2). The experiment was made with five replicates, of which one was used for sampling 80 days after sowing. Nitrogen was added as $\mathrm{NH}_{4} \mathrm{NO}_{3}$. Treatments with $\mathrm{NaCl}$ and $\mathrm{Na}_{2} \mathrm{SO}_{4}$ contained equal amounts of $\mathrm{Na}$.
Table 2. Fertilization treatments in the pot and field experiments.

Pot experiment

A. Nitrogen application $/ 1 \mathrm{~kg}$ soil

$\begin{array}{ll}\mathrm{N}_{0} & 0 \mathrm{mg} \\ \mathrm{N}_{250} & 250 \mathrm{mg} \\ \mathrm{N}_{500} & 500 \mathrm{mg} \\ \mathrm{N}_{750} & 750 \mathrm{mg} \\ \mathrm{N}_{500+250} & \left.500 \mathrm{mg}+250 \mathrm{mg}^{*}\right)\end{array}$

B. Chloride application / $1 \mathrm{~kg}$ soil

$\mathrm{S}_{113} \quad 0 \mathrm{mg}(\mathrm{Na} 163 \mathrm{mg}, \mathrm{S} 113 \mathrm{mg})$

$\mathrm{S}_{225} \quad 0 \mathrm{mg}(\mathrm{Na} 325 \mathrm{mg}, \mathrm{S} 225 \mathrm{mg})$

$\mathrm{Cl}_{2 \varsigma_{0}} \quad 250 \mathrm{mg}$ ( Na $\left.163 \mathrm{mg}\right)$

$\mathrm{Cl}_{500} \quad 400 \mathrm{mg}$ ( Na $325 \mathrm{mg}$ )

*) $250 \mathrm{mg}$ was given 54 days after sowing

Field experiment

A. Nitrogen fertilization /hectare

$\begin{array}{ll}\mathrm{N}_{100} & 100 \mathrm{~kg} \\ \mathrm{~N}_{200} & 200 \mathrm{~kg}\end{array}$

B. Chloride fertilization/ hectare

B. Chloride fertilization/ hectare
$\mathrm{S}_{44}$
$0 \mathrm{~kg}(\mathrm{~K} 100 \mathrm{~kg}, \mathrm{~S} 44 \mathrm{~kg})$

$\mathrm{S}_{88} \quad 0 \mathrm{~kg}(\mathrm{~K} 200 \mathrm{~kg}, \mathrm{~S} 88 \mathrm{~kg})$

$\mathrm{Cl}_{95} \quad 95 \mathrm{~kg}(\mathrm{~K} 100 \mathrm{~kg})$

$\mathrm{Cl}_{190} \quad 190 \mathrm{~kg}$ (K $\left.200 \mathrm{~kg}\right)$

Basic fertilization was given as powdered PKfertilizer (P $7.0 \%$, K $16.6 \%$ ) $10 \mathrm{~g}$ per pot. Other nutrients of this fertilizer were: N $2.0 \%$, Ca $5.4 \%$, $\mathrm{S} 12.0 \%$, Mg $2.5 \%$, Na $0.5 \%$, Fe $0.1 \%$, Cl $0.7 \%$, B $0.15 \%$, Cu $0.1 \%$, Mn $0.7 \%$, Zn $0.1 \%$, Mo 0.01 $\%$ and Se $0.0016 \%$. The additional boron $(10 \mathrm{mg}$ per pot) was added as boric acid. The soil was limed with $\mathrm{CaCO}_{3}$ at the rate of $18 \mathrm{~g}$ per pot because of low $\mathrm{pH}$ value. The liming material as well as the fertilizing powder and solutions were thoroughly mixed in the soil.

Four kilograms of the fertilized soils (moisture around $55 \%$ on bulk basis) were put into 61 plastic pots and compacted slightly. Twenty seeds per pot were placed on the surface and covered with a $2 \mathrm{~cm}$ 
layer of fertilized soil. The beetroot cultivar was 'Little Ball SG', which is a common beetroot cultivar in Finland. A week after emergence the plants were thinned to 12 plants per pot. The plants were watered with de-ionized water once or twice a day. The percolated water was collected and reused.

The first root and shoot samples were collected 54 days after sowing when the plants in the whole experiment were thinned to 6 plants per pot. The second sampling was carried out 80 days after sowing by harvesting one replicate. The other four replicates were harvested 96 days after sowing.

The shoot and root yields were measured. The roots were grated and frozen at $-20^{\circ} \mathrm{C}$ for laboratory analyses. The nitrate nitrogen content was analysed with a nitrate electrode (ORION 1983, AURA 1985). For the determination of dry matter content, samples were dried at $60^{\circ} \mathrm{C}$ for 48 hours.

The results were analysed using the analysis of variance of split-plot design, and Tukey's HSD (Honestly Significant Difference) test was used to determine the significances $(\mathrm{p}=0.05)$ of differences between group means (STEEL and TORRIE 1981).

\section{Field experiment}

The field experiment was set up according to a split-plot design, where the main plot was nitrogen fertilization $\left(\mathrm{N}_{100}, \mathrm{~N}_{200}\right)$ and the subplot was $\mathrm{K}_{2} \mathrm{SO}_{4}$ or $\mathrm{KCl}$ fertilization $\left(\mathrm{S}_{44}, \mathrm{~S}_{88}, \mathrm{Cl}_{95}, \mathrm{Cl}_{190}\right)$. The treatments are presented in Table 2. The experiment was made with four replicates. Nitrogen fertilization was applied as ammonium nitrate limestone $\left(13.8 \% \mathrm{NH}_{4}-\mathrm{N} ; 13.7 \% \mathrm{NO}_{3}-\mathrm{N}\right), 70 \%$ in spring and $30 \%$ ten weeks after sowing. In $\mathrm{K}_{2} \mathrm{SO}_{4}$ and $\mathrm{KCl}$ fertilizations equal amounts of $\mathrm{K}$ were given.

Because of the good nutrient status of the soil (Table 1) the only basic fertilization given was 200 $\mathrm{kg}$ superphosphate $(20 \% \mathrm{P})$. Potassium chloride and potassium sulphate were applied with TuplaTume fertilizer drill. Superphosphate and ammonium nitrate limestone were broadcasted by a manually used fertilizer spreader working on the principle of an ordinary fertilizer drill. The fertilizers were harrowed into the depth of $5 \mathrm{~cm}$. The tractor drove along traffic lanes to avoid soil compaction. The distance of the tractor wheels was $2 \mathrm{~m}$, which was also the width of the subplots.

Seeds were sown $3 \mathrm{~cm}$ deep at a row distance of $40 \mathrm{~cm}$ by a Nibex sowing machine. The plants were later thinned to 25 plants $/ \mathrm{m}$. There were four rows in a plot, $10 \mathrm{~m}$ each. Phenmedipham was sprayed with weed control and dimethoate was applied three times against tarnished plant bug (Lygus rugulipennis).

Topsoil $(20 \mathrm{~cm})$ samples were taken $11,66,77$, 91, 111 and 146 days after sowing from two replicates. The first and the second samples were taken from between the middle and edge rows, and the other samplings from places, where beetroots were grown for plant samples. Soil mineral nitrogen was extracted with $2 \mathrm{M} \mathrm{KCl}$ (KEENEY and NELSON 1982) and analyzed with a Skalar autoanalyzer (Krom 1980, GreENBERG et al. 1980).

Root samples were taken 75, 82, 89, 97, 102 and 117 days after sowing to determine the nitrate content of roots. The samples were taken from the edges of the middle rows along a length of one meter. Sampling was always done between 8.00 and 10.00 a.m. because of the diurnal change in the nitrate content. Samples were prepared and nitrate contents determined like in the pot experiment.

The root and shoot yields were harvested and measured 102 days after sowing along a length of 4 $\mathrm{m}$ from two middle rows $(=8 \mathrm{~m})$. The beetroots were classified according to root diameter into three classes: $<4 \mathrm{~cm}, 4-8 \mathrm{~cm}$ and $>8 \mathrm{~cm}$. There were no roots larger than $8 \mathrm{~cm}$ in diameter. Some beetroots were left in the edges of the plots for determination of nitrate content later in autumn.

Statistical analysis was made using multivariate analysis of variance to test differences between treatments in all six plant samplings (LITTELL et al. 1991). The analysis of variance and Tukey's HSD test were used to test significances of differences between group means of samplings (STEEL and TORRIE 1981). 
Table 3. Effect of different fertilization treatments on soil EC, and nitrate content, yield and dry matter content of beetroot in the pot experiment.

\begin{tabular}{|c|c|c|c|c|c|c|c|}
\hline \multicolumn{2}{|c|}{$\begin{array}{l}\text { Fertilizations, } \\
\text { mg/kg soil }\end{array}$} & \multirow[t]{2}{*}{$\begin{array}{l}\text { Soil EC } \\
10^{-4} \mathrm{~S} / \mathrm{cm}\end{array}$} & \multicolumn{2}{|c|}{$\begin{array}{l}\text { Nitrate content in } \\
\text { roots, ppm in FW } \\
\text { Days after sowing }\end{array}$} & \multicolumn{2}{|c|}{$\begin{array}{l}\text { Final } \\
\text { yield in FW } \\
\text { g/ } 6 \text { plants }\end{array}$} & \multirow{2}{*}{$\begin{array}{l}\text { Dry matter } \\
\text { content } \\
\% \text { in root } \\
\text { yield }\end{array}$} \\
\hline & & & 54 & 96 & root & shoot & \\
\hline \multirow[t]{4}{*}{ No } & $\mathrm{Cl}_{0}\left(\mathrm{~S}_{113}\right)$ & $6.4^{b}$ & 14 & 22 & 35 & 39 & \\
\hline & $\mathrm{Cl}_{0}\left(\mathrm{~S}_{225}\right)$ & $8.0^{\mathrm{a}}$ & 14 & 45 & 37 & 42 & \\
\hline & $\mathrm{Cl}_{250}$ & $6.2^{\mathrm{b}}$ & 29 & 31 & 33 & 48 & \\
\hline & $\mathrm{Cl}_{500}^{50}$ & $8.5^{\mathrm{a}}$ & 47 & 32 & 35 & 52 & \\
\hline \multirow[t]{4}{*}{$\mathrm{N} 250$} & $\mathrm{Cl}_{0}\left(\mathrm{~S}_{113}\right)$ & $4.9^{b}$ & 78 & 17 & 235 & 89 & 16.8 \\
\hline & $\mathrm{Cl}_{0}\left(\mathrm{~S}_{225}\right)$ & $6.8^{a}$ & 107 & 23 & 260 & 91 & 15.9 \\
\hline & $\mathrm{Cl}_{250}$ & $4.4^{b}$ & 61 & 25 & 255 & 89 & 15.8 \\
\hline & $\mathrm{Cl}_{500}$ & $4.9^{b}$ & 124 & 27 & 305 & 120 & 17.0 \\
\hline \multirow[t]{4}{*}{ N500 } & $\mathrm{Cl}_{0}\left(\mathrm{~S}_{113}\right)$ & $5.0^{\mathrm{b}}$ & 951 & 31 & 396 & 165 & 15.5 \\
\hline & $\mathrm{Cl}_{0}\left(\mathrm{~S}_{225}\right)$ & $7.2^{\mathrm{a}}$ & 1220 & 54 & 379 & 173 & 15.0 \\
\hline & $\mathrm{Cl}_{250}$ & $4.3^{b}$ & 896 & 26 & 443 & 205 & 14.6 \\
\hline & $\mathrm{Cl}_{500}$ & $4.3^{\mathrm{b}}$ & 1360 & 36 & 413 & 202 & 14.1 \\
\hline \multirow[t]{4}{*}{ N750 } & $\mathrm{Cl}_{0}\left(\mathrm{~S}_{113}\right)$ & $5.3^{b}$ & $2240^{\mathrm{ab}}$ & 124 & 496 & $239^{b}$ & 13.6 \\
\hline & $\mathrm{Cl}_{0}\left(\mathrm{~S}_{225}\right)$ & $7.3^{\mathrm{a}}$ & $2760^{a}$ & 192 & 495 & $247^{\mathrm{ab}}$ & 12.2 \\
\hline & $\mathrm{Cl}_{25_{0}}$ & $3.9^{c}$ & $2320^{\mathrm{ab}}$ & 98 & 535 & $249^{\mathrm{ab}}$ & 13.4 \\
\hline & $\mathrm{Cl}_{500}$ & $3.7^{\mathrm{c}}$ & $1880^{b}$ & 144 & 573 & $294^{a}$ & 13.6 \\
\hline \multicolumn{8}{|c|}{$\mathrm{N} 500+250$} \\
\hline & $\mathrm{Cl}_{0}\left(\mathrm{~S}_{113}\right)$ & $4.8^{\mathrm{b}}$ & & $196^{\mathrm{a}}$ & 519 & 243 & 13.3 \\
\hline & $\mathrm{Cl}_{0}\left(\mathrm{~S}_{225}\right)$ & $6.1^{\mathrm{A}}$ & & $168^{a}$ & 528 & 248 & 13.8 \\
\hline & $\mathrm{Cl}_{250}$ & $3.6^{c}$ & & $66^{\mathrm{ab}}$ & 583 & 224 & 13.8 \\
\hline & $\mathrm{Cl}_{500}$ & $3.8^{c}$ & & $40^{b}$ & 579 & 259 & 13.3 \\
\hline \multicolumn{8}{|c|}{$\mathrm{N}$ levels } \\
\hline & $\mathrm{N}_{0}$ & $7.3^{\mathrm{a}}$ & $26^{c}$ & 32 & $35^{\mathrm{d}}$ & $45^{\mathrm{d}}$ & \\
\hline & $\mathrm{N}_{250}$ & $5.2^{\mathrm{b}}$ & $93^{\mathrm{c}}$ & 23 & $264^{c}$ & $97^{c}$ & $16.4^{a}$ \\
\hline & $\mathrm{N}_{500}$ & $5.2^{\mathrm{b}}$ & $1110^{b}$ & 37 & $408^{b}$ & $186^{b}$ & $14.8^{\mathrm{ab}}$ \\
\hline & $\mathrm{N}_{750}$ & $5.1^{\mathrm{b}}$ & $2300^{\mathrm{a}}$ & 139 & $525^{\mathrm{a}}$ & $257^{a}$ & $13.2^{\mathrm{b}}$ \\
\hline & $\mathrm{N}_{500+250}$ & $4.6^{b}$ & & 117 & $552^{\mathrm{a}}$ & $243^{a}$ & $13.5^{\mathrm{ab}}$ \\
\hline \multicolumn{8}{|c|}{$\mathrm{Cl}$ levels } \\
\hline & $\mathrm{Cl}_{0}\left(\mathrm{~S}_{113}\right)$ & $5.3^{\mathrm{b}}$ & 820 & 78 & 336 & $155^{b}$ & 14.8 \\
\hline & $\mathrm{Cl}_{0}\left(\mathrm{~S}_{225}\right)$ & $7.1^{\mathrm{a}}$ & 1020 & 96 & 340 & $160^{b}$ & 14.2 \\
\hline & $\mathrm{Cl}_{250}$ & $4.5^{\mathrm{c}}$ & 830 & 49 & 370 & $163^{b}$ & 14.4 \\
\hline & $\mathrm{Cl}_{500}$ & $5.0^{\mathrm{bc}}$ & 850 & 56 & 381 & $186^{\mathrm{a}}$ & 14.5 \\
\hline
\end{tabular}

* 1 replicate

Figures without a common superscript letter are significantly different $(p<0.05)$. Figures without superscript letters have no significant differences. 


\section{Results}

\section{Pot experiment}

On average, the nitrate contents remained low in the pot experiment (Table 3 ). Towards the middle of the growing period, 54 days after sowing, the nitrate contents were about ten times higher than at harvest time, the nitrate values increasing with increasing nitrogen levels.

The effect of chloride application on the nitrate contents was not so clear as the effect of nitrogen. Towards the middle of the growing period, chloride decreased the nitrate accumulation significantly $(p=0.05)$ only in the treatment of maximum nitrogen and chloride levels. In these samples, the nitrate contents were $2200-2800$ ppm in FW below the highest chloride level, but $1900 \mathrm{ppm}$ at the highest chloride level.

Two weeks before harvesting and at harvest the nitrate contents were very low. Consequently, the nitrate content was not significantly dependent even on the nitrogen fertilization. However, in the treatment of additional nitrogen fertilization 54 days after sowing, chloride application still decreased the nitrate concentrations. The differences were significant $(\mathrm{p}=0.05)$ between the groups of highest chloride level and lowest sulphate level.

Towards the middle of the growing period, at nitrogen levels of 200 and $400 \mathrm{mg} / \mathrm{kg}$ soil, more nitrate was accumulated at the highest sodium level. The effect of $\mathrm{Na}_{2} \mathrm{SO}_{4}$ can be explained by an increase in soil EC (Table 3) caused by this treatment.

Even though the seedlings emerged slowly in the pots given high rates of $\mathrm{NaCl}$, both root and shoot yields were the highest on the highest chloride supply. In shoot yield the difference between low $\mathrm{Na}_{2} \mathrm{SO}_{4}$ and high $\mathrm{NaCl}$ levels was significant $(p=0.05)$. Nitrogen application decreased the dry matter content of roots significantly $(\mathrm{p}=0.05)$, but chloride had no effect on the dry matter content.

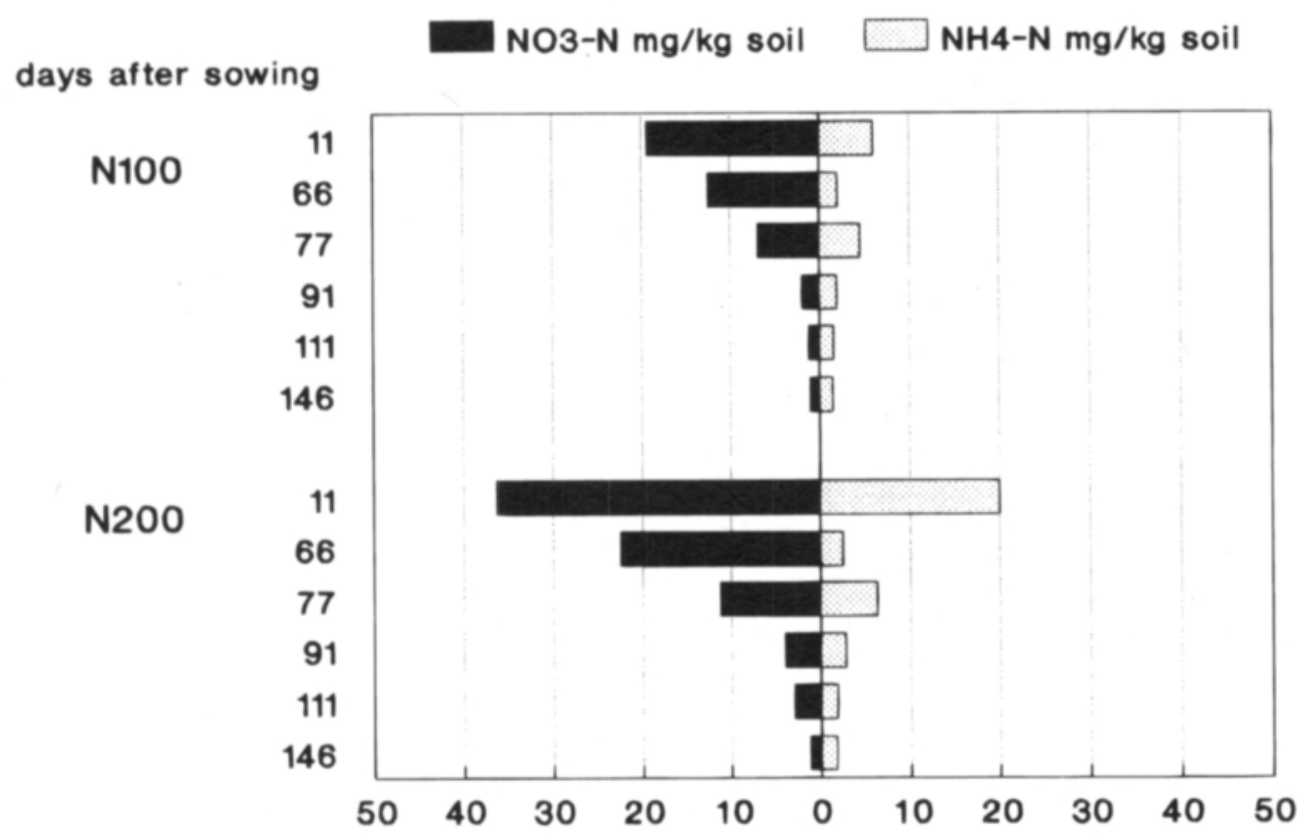

Fig. 1. Soil mineral nitrogen contents in a field experiment during the growing season of 1990 . 


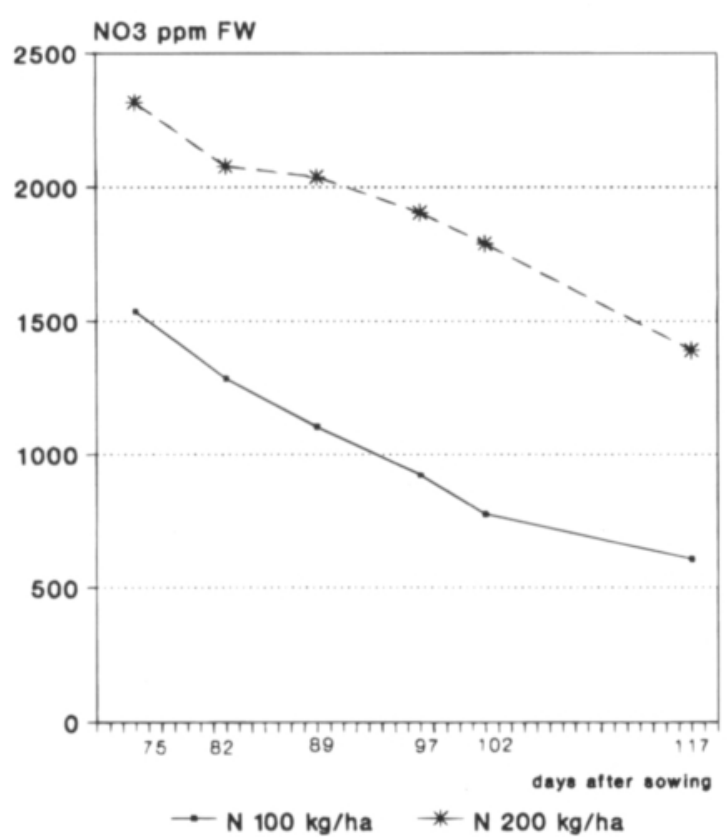

Fig. 2. Nitrate contents in roots of beetroot during the growing season of 1990 at two rates of nitrogen fertilization.

\section{Field experiment}

Nitrate nitrogen in soil decreased continuously during the growing season (Fig. 1). The difference in soil nitrate contents between two nitrogen treatments was almost double until October. The soil ammonium nitrogen level was low 66 days after sowing. Nitrogen application 67 days after sowing doubled the amount of soil ammonium after two weeks. Then it dropped to a constant low level in two weeks.

The nitrate contents of roots decreased significantly $(\mathrm{p}=0.01)$ during the period between 75 and 117 days after sowing. At the nitrogen level of 200 $\mathrm{kg} / \mathrm{ha}$, the fresh roots had on average $900 \mathrm{ppm}$ higher nitrate contents than in the nitrogen treatment of $100 \mathrm{~kg} / \mathrm{ha} \mathrm{(Fig.} \mathrm{2).} \mathrm{The} \mathrm{difference} \mathrm{was} \mathrm{statistically}$ significant $(\mathrm{p}=0.01)$.

There was no significant difference in nitrate accumulation between $\mathrm{KCl}$ and $\mathrm{K}_{2} \mathrm{SO}_{4}$ applications according to the multivariate analysis of variance

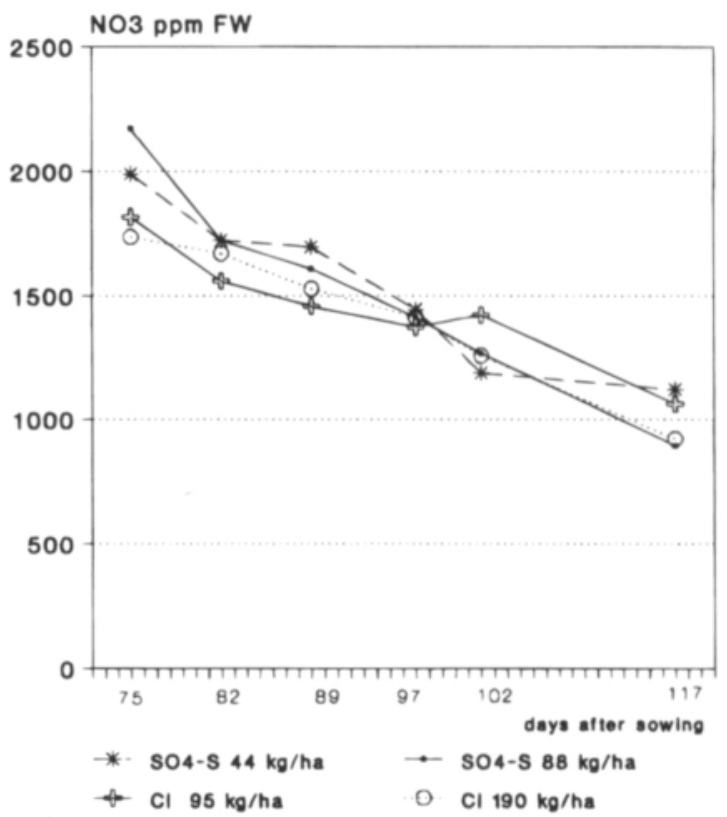

Fig. 3. Nitrate contents in roots of beetroot during the growing season of 1990 at different rates of chloride and sulphate fertilization.

(Fig. 3). When every sampling was compared separately using the analysis of variance, there was a significant difference in the first sampling, 75 days after sowing. The fertilization of $\mathrm{SO}_{4}-\mathrm{S} 88 \mathrm{~kg} / \mathrm{ha}$ caused about $400 \mathrm{ppm}$ higher nitrate content in fresh roots than the chloride treatments.

As compared with the nitrogen fertilization of $100 \mathrm{~kg} / \mathrm{ha}$, the nitrogen level of $200 \mathrm{~kg} / \mathrm{ha}$ had a significant $(\mathrm{p}=0.01)$ positive influence on the root and shoot yield. The application of $\mathrm{KCl}$ caused higher shoot yield but no higher root yield compared with $\mathrm{K}_{2} \mathrm{SO}_{4}$ fertilization (Table 4).

According to the multivariate analysis of variance, the nitrogen fertilization of $200 \mathrm{~kg} / \mathrm{ha}$ had a significant $(\mathrm{p}=0.01)$ decreasing influence on the dry matter content of roots (Table 5). The fertilization of $\mathrm{KCl}$ decreased the dry matter content of roots significantly $(\mathrm{p}=0.01)$ compared with $\mathrm{K}_{2} \mathrm{SO}_{4}$ fertilization. The dry matter contents decreased 89 days after sowing, because of heavy rainfalls after a dry period of two weeks. 
Table 4. Effect of different fertilizing treatments on root and shoot yield of beetroot in the field experiment.

\begin{tabular}{|c|c|c|c|c|}
\hline \multirow{4}{*}{$\begin{array}{l}\text { Fertilizations, } \\
\mathrm{kg} / \mathrm{ha}\end{array}$} & Shoot yield & \multirow{2}{*}{\multicolumn{2}{|c|}{$\begin{array}{l}\text { Root yield } \\
\text { Size distribution }\end{array}$}} & \multirow{4}{*}{ sum } \\
\hline & \multirow[b]{3}{*}{$\operatorname{tn} / \mathrm{ha} \mathrm{FW}$} & & & \\
\hline & & $<4 \mathrm{~cm}$ & $4-8 \mathrm{~cm}$ & \\
\hline & & & /ha FW & \\
\hline \multicolumn{5}{|l|}{ Nitrogen } \\
\hline $\mathrm{N}_{100}$ & $11.98^{\mathrm{a}}$ & $5.33^{\mathrm{a}}$ & $14.78^{a}$ & $20.11^{\mathrm{a}}$ \\
\hline $\mathrm{N}_{200}$ & $19.21^{\mathrm{b}}$ & $3.85^{b}$ & $24.63^{b}$ & $28.49^{b}$ \\
\hline \multicolumn{5}{|c|}{ Sulphate-S and chloride } \\
\hline $\mathrm{S}_{44}$ & $13.74^{c}$ & 5.30 & 17.91 & 23.21 \\
\hline $\mathrm{S}_{88}$ & $14.43^{\mathrm{bc}}$ & 4.84 & 19.84 & 24.67 \\
\hline $\mathrm{Cl}_{95}$ & $16.23^{\mathrm{ab}}$ & 4.04 & 21.30 & 25.34 \\
\hline $\mathrm{Cl}_{190}$ & $17.98^{\mathrm{a}}$ & 4.19 & 19.78 & 23.97 \\
\hline
\end{tabular}

Main and sub plot means without a common superscript letter are significantly different $(p<0.05)$. Means without superscript letters have no significant differences.

\section{Discussion}

The nitrate contents decreased both in the pot and in the field experiments during the growing season. This decrease has been noticed also by PECK et al. (1974) and Kallio et al. (1980).

Nitrogen fertilizers increase the nitrate content and yield of beetroot (PECK et al. 1971). This has been noticed also in Finland (AURA 1985), where the recommended nitrogen fertilization level for optimal beetroot yield has been $60-120 \mathrm{~kg} / \mathrm{ha}$ (LEHTINEN 1984, VUORINEN and TAKALA 1987). Nitrogen levels over $120 \mathrm{~kg} / \mathrm{ha}$ impair the quality by increasing the nitrate content. In some experiments even the yield has decreased (LEHTINEN 1984). However, differences between growing seasons cause a great deal of variation in beetroot yields, and it is difficult to estimate the nitrogen requirement for optimal yield production.

Table 5. Effect of different fertilization treatments on dry matter content of beetroot roots in the field experiment.

\begin{tabular}{|c|c|c|c|c|c|c|}
\hline & \multicolumn{6}{|c|}{ Days after sowing } \\
\hline & 75 & 82 & 89 & 97 & 102 & 117 \\
\hline \multicolumn{7}{|c|}{$\begin{array}{l}\text { Fertilization, } \\
\mathrm{kg} / \mathrm{ha}\end{array}$} \\
\hline $\mathrm{N}_{100} \mathrm{~S}_{44}$ & 10.7 & 13.1 & 10.1 & 12.0 & 12.9 & 14.7 \\
\hline $\mathrm{N}_{100}^{100} \mathrm{~S}_{88}$ & 10.7 & 12.7 & 9.9 & 12.1 & 13.3 & 15.0 \\
\hline $\mathrm{N}_{100} \mathrm{Cl}_{95}$ & 10.4 & 12.5 & 9.7 & 10.6 & 12.2 & 14.4 \\
\hline $\mathrm{N}_{100} \mathrm{Cl}_{190}$ & 10.3 & 12.1 & 9.4 & 11.0 & 12.9 & 14.7 \\
\hline $\mathrm{N}_{200} \mathrm{~S}_{44}$ & 10.2 & 12.5 & 9.5 & 10.8 & 12.3 & 13.6 \\
\hline $\mathrm{N}_{200}^{200} \mathrm{~S}_{44}$ & 9.9 & 12.4 & 9.7 & 10.6 & 12.2 & 14.6 \\
\hline $\mathrm{N}_{200} \mathrm{Cl}_{95}$ & 9.9 & 11.5 & 9.7 & 10.5 & 11.4 & 13.5 \\
\hline $\mathrm{N}_{200} \mathrm{Cl}_{190}$ & 10.0 & 11.8 & 9.4 & 10.2 & 11.5 & 13.7 \\
\hline \multicolumn{7}{|l|}{ Nitrogen } \\
\hline $\mathrm{N}_{100}$ & 10.5 & $12.6^{\mathrm{a}}$ & 9.8 & 11.4 & $12.9^{\mathrm{a}}$ & 14.7 \\
\hline $\mathrm{N}_{200}^{100}$ & 10.0 & $12.0^{\mathrm{b}}$ & 9.3 & 10.5 & $11.8^{\mathrm{b}}$ & 13.8 \\
\hline \multicolumn{7}{|c|}{ Sulphate-S and chloride } \\
\hline $\mathrm{S}_{44}$ & 10.4 & 12.8 & 9.8 & $11.4^{a}$ & $12.6^{\mathrm{a}}$ & $14.2^{\mathrm{ab}}$ \\
\hline $\mathrm{S}_{88}$ & 10.3 & 12.5 & 9.8 & $11.3^{\mathrm{a}}$ & $12.8^{\mathrm{a}}$ & $14.8^{\mathrm{a}}$ \\
\hline $\mathrm{Cl}_{95}$ & 10.2 & 12.0 & 9.2 & $10.6^{\mathrm{b}}$ & $11.8^{\mathrm{b}}$ & $13.9^{b}$ \\
\hline $\mathrm{Cl}_{190}$ & 10.2 & 12.0 & 9.4 & $10.6^{b}$ & $12.2^{\mathrm{ab}}$ & $14.2^{\mathrm{ab}}$ \\
\hline
\end{tabular}

Main and sub plot means without a common superscript letter are significantly different $(\mathrm{p}<0.05)$. Means without superscript letters have no significant differences. 
Nitrogen decreased the dry matter contents from 0.5 to 1.0 percentage units, which is in agreement with the results of AURA (1985). Chloride decreased the dry matter contents only in the field experiment.

In the pot experiment, high levels of both nitrogen and chloride were needed in order to decrease nitrate accumulation. In the final yield no differences were observed as the beetroots used all nitrogen because of good growing conditions.

In the field experiment, chloride decreased the nitrate content only in the first sampling, 75 days after sowing, which was 8 days after additional application of ammonium nitrate limestone. Thus, it may be assumed that chloride needs ammoniumnitrogen in order to decrease the nitrate accumulation in beetroot. A similar conclusion was drawn by van der Boon et al. (1988) concerning lettuce. They used nutrient solutions, where it is easy to control the ion concentrations. In field conditions it is very difficult to maintain sufficiently high ammonium levels in soil because of nitrification.

Nitrification inhibitors together with ammonium and urea fertilizers tend to decrease the nitrate accumulation, but high rates of nitrogen application involve a risk of ammonium toxicity ( $\mathrm{GOH}$ and VITYAKON 1983, HÄHNDEL and WEHRMANN 1986 a). KALLIO et al. (1980) found that nitrapyrin caused a $30 \%$ reduction of nitrate content. In their field experiment, no differences were found in the nitrate content of yield between $\mathrm{KCl}$ and $\mathrm{K}_{2} \mathrm{SO}_{4}$ applications, when the amount of potassium was $150 \mathrm{~kg} / \mathrm{ha}$. According to CANTLIFFE and GoODWIN (1974), chloride containing fertilizers reduced the nitrate concentration at harvest time in the beetroot petioles, but not in the roots or the blades.

Potassium chloride caused higher root yields in the pot experiment and higher shoot yields in both experiments than potassium sulphate. This suggests that chloride may promote the growth of beetroot more than sulphate. GoH and VITYAKON (1983) obtained higher yields with $\mathrm{NH}_{4} \mathrm{Cl}$ than with $\left(\mathrm{NH}_{4}\right)_{2} \mathrm{SO}_{4}$ in a pot experiment. There are also indications of chloride being an important micronutrient for beet species (JOHNSON et al. 1957).

In the present experiments chloride seemed to decrease nitrate accumulation only at the early developmental stage of beetroot and on sufficient supply of ammonium-nitrogen. This effect of chloride may be useful in the production of fresh vegetables for early marketing in summer. However, the exact effect of the developmental stage of beetroot, the form of nitrogen and chloride fertilizers on the accumulation of nitrate in beetroot should be determined in controlled conditions, e.g. growing beetroots in recirculating nutrient solutions.

\section{Contributions of authors}

Salo, T. Final manuscript and field experiment.

Pietola, L. Pot experiment.

Jokinen, R. The original idea of the present study and planning of the pot experiment with L.Pietola.

\section{References}

Allen, S. \& Smith, J.A.C. 1986. Ammonium nutrition in Ricinis communis: Its effects on plant growth and the chemical composition of the whole plant, xylem and phloem saps. J. Exp. Bot. 37: 1599-1610.

AURA, E. 1985. Avomaan vihannesten veden ja typen tarve. Nitrogen and water requirements for carrot, beetroot, onion and cabbage. Maatalouden tutkimuskeskus, Tiedote $7 / 85.61 \mathrm{p}$.

Boon, J. van der, Steenhuizen, J.W. \& Steingröver, E. 1988. Effect of EC, and $\mathrm{Cl}$ and $\mathrm{NH}_{4}$ concentration of nutrient solutions on nitrate accumulation in lettuce. Acta
Hortic. 222: 35-43.

CANTliffe, D.J. \& Goodwin, P.R. 1974. Effects of nitrogen rate, source, and various anions and cations on $\mathrm{NO}_{3}$ accumulation and nutrient constituents of table beets. Agron. J. 66: 779-783.

Elonen, P. 1971. Particle-size analysis of soil. Acta Agric. Fenn. 122: 1-122.

Goh, K.M. \& Vityakon, P. 1983. Effects of fertilisers on vegetable production. 1. Yield of spinach and beetroot as affected by rates and forms of nitrogenous fertilisers. N. Z. J. Agric. Res. 26: 349-356. 
Greenberg, A., Connors, J. \& Jenkins, D. 1980. Nitrogen (Nitrate). Standard methods; For the examination of water and wastewater. p. 391-404. 15th Ed. Washington.

HÄHNDEL, R. \& WEHRMANN, J. 1986 a. Einfluss der $\mathrm{NO}_{3}$ Ernăhrung auf Ertrag und Nitratgehalt von Spinat und Kopfsalat. Z. Pflanzenernähr. Bodenk. 149: 290-302.

— \& Wehrmann, J. 1986 b. Einfluss der Cl-ernăhrung auf Ertrag und Nitratgehalt von Spinat und Kopfsalat. Z. Pflanzenernăhr. Bodenk. 149: 303-319.

James, D.W., Kidman, D.C., WeAVER, W.H. \& ReEDER, R.L. 1970. Factors affecting chloride uptake and implications of the chloride-nitrate antagonism in sugarbeet mineral nutrition. J. Am. Soc. Sugar Technol. 15: 647656.

Johnson, C.M., Stout, P.R., Broyer, T.C. \& CARlton, A.B. 1957. Comparative chlorine requirements of different plant species. Plant and Soil 8: 337-353.

Kallio, H., Linko, R.R., TikanmäKI, E. \& PUNTARI, I. 1980. Effect of nitrapyrin on nitrapyrin residues and nitrate content in red beet roots fertilised with urea. J. Sci. Food Agric. 31: 701-708.

KEENEY, D.R. \& Nelson, D.W. 1982. Nitrogen - Inorganic forms. Methods of soil analysis. Part 2. Chemical and microbiological Properties. Agronomy 9. p. 643-698. Madison. Wisconsin.

KROM, M.D. 1980. Spectrophotometric determination of ammonia: A study of a modified Berthelot reaction using salicylate and dichloroisocyanurate. Analyst 105: 305316.

Kurki, M., LaKanen, E., MÃ̈ItIE, O. \& SillanpäÃ, M. 1965. Viljavuusanalyysien ilmoitustapa ja tulkinta. Interpration of soil testing results. Ann. Agric. Fenn. 4: 145-153.

LeHTINEN, S. 1984. Avomaanvihannesten lannoitus- ja kastelukokeet 1978-1983. Maatalouden tutkimuskeskus, Tiedote 21/84. p. 1-62.

Littell, R.C., Freund, R.J. \& Spector, P.C. 1991. SASsystem for linear models. 329 p. 3rd ed. Cary, NC.

ORION 1983. Guide to ion analysis. 45 p. Massachusetts.
Peck, N.H., Barker, A.V., MacDonald, G.E. \& ShallenBERGER, R.S. 1971. Nitrate accumulation in vegetables. II. Table beets grown in upland soils. Agron J. 63: 130132.

-, Cantliffe, D.J., Shallenberger, R.S. \& Bourke, J.B. 1974. Table beet and nitrogen. N.Y. Agric. Exp. Sta. Geneva. Search Agric. 4, 6: 1-25.

Penttilia, P.-L., RĀSĀnen, L. \& KimpPa, S. 1990. Nitrate, nitrite, and N-nitroso compounds in Finnish foods and the estimation of dietary intakes. Z. Lebensm. Unters. Forsch. 190: 336-340.

SiPPOLA, J. 1982. A comparison between a drycombustion method and a rapid wetcombustion method for determining soil organic carbon. Ann. Agric. Fenn. 21: 146-148.

— \& ERVIÖ, R. 1977. Determination of boron in soils and plants by the azomethine-H method. Finn. Chem. Lett. 1977: 138-140.

Steel, R.G.D. \& Torrie, J.H. 1981. Principles and procedures of statistics. 633 p. 2nd ed. Singapore.

VUORINEN, J. \& MÄKITIE, O. 1955. The method of soil testing in use in Finland. Agrogeol. Publ. 63: 1-44.

VuORINEN, M. \& TAKAlA, M. 1987. Porkkanan ja punajuurikkaan sadetus, typpilannoitus ja kalkitus poutivalla hiekkamaalla. Maatalouden tutkimuskeskus, Tiedote 10/87. p. 1-30.

\section{Manuscript received November 1991}

Tapio Salo

Liisa Pietola

Raili Jokinen

Agricultural Research Centre of Finland

Institute of Crop and Soil Science

SF-31600 Jokioinen, Finland

Raili Jokinen

Present address:

Tyynelä

SF-03250 Ojakkala, Finland 


\title{
SELOSTUS
}

\section{Kloridi- ja typpilannoituksen vaikutus punajuurikkaan nitraattipitoisuuteen ja satoon}

\author{
Tapio Salo, LiISA Pietola ja Raili Jokinen \\ Maatalouden tutkimuskeskus
}

Vihannesten korkeat nitraattipitoisuudet ovat terveydelle haitallisia, koska nitraatti voi muuttua nitriitiksi aiheuttaen methemoglobinemiaa tai karsinogeenisiksi nitrosoamiineiksi. Pinaatti, salaatit, retiisi ja punajuurikas sisältävät yleensä runsaasti nitraattia.

Astia- ja kenttäkokeessa seurattiin eri kloridi- ja typpilannoitustasojen vaikutusta punajuurikkaan nitraattipitoisuuteen, satoon ja kuiva-ainepitoisuuteen. Sulfaattilannoitusta verrattiin kloridilannoitukseen.

Punajuurikkaiden nitraattipitoisuus laski huomattavasti kasvukauden aikana. Runsas typpilannoitus lisăsi satoa ja nitraatin kertymistä molemmissa kokeissa. Astiakokeessa myös kloridin lisäys kohotti satoa. Typpilannoitus laski kuiva-ainepitoisuutta kenttä- ja astiakokeessa, mutta kloridi alensi kuiva-ainepitoisuutta vain kenttäkokeessa.

Kloridi văhensi merkitsevästi nitraatin kertymistä kasvukauden puolivälissä astiakokeessa. Kenttäkokeessa kloridi laski nitraattipitoisuutta myös kasvukauden puolivälissä, pian oulunsalpietarina annetun täydennystyppilannoituksen jälkeen. Kloridi näyttääkin vähentävän nitraatin kertymistä punajuurikkaalla vain juurikkaan aikaisessa kehitysvaiheessa, kun nitraatti ei ole ainoa typen lähde maassa. 